\title{
Model Pembelajaran Kooperatif Tipe Jigsaw Meningkatkan Hasil Belajar
}

\author{
Haerati, Nurdin K, Mardi Takwim \\ Prodi Pendidikan Agama Islam, IAIN Palopo \\ Email:haerati90@gmail.com
}

\begin{abstract}
This research talk about model jigsaw on the subjects of moral all students viii modern class boarding datok solomon the son of palopo, but the problem is basic: how the application of learning model type and cooperative jigsaw investigating whether the application of learning model cooperative type jigsaw can improve study results.The research is class action research but the data from the study is students viii modern class boarding datok solomon the son of palopo when applied method of learning cooperative type jigsaw to obtain data researchers used technique observation and tests. Analysis of data conducted using qualitative analysis descriptive and quantitative. The research results show that using learning cooperative type jigsaw students study results any siklusnya changed significantly.Respectively the I and based on the study results moral ii is with subject matter believe in the books.I cycle is in the highest and the lowest 87 is 70.11 cycle is in the highest and the lowest 95 is 80, average analysis procurement value the students in i am 80,14 II average in the procurement value increased by 88,32 students
\end{abstract}

Keywords: Kooperatife Learning, Jigsaw Type, learning outcomes, Islamic Education

\begin{abstract}
Abstrak
Penelitian ini membahas tentang Model Jigsaw pada Mata Pelajaran Akidah Akhlak Peserta Didik Kelas VIII Pesantren Modern Datok Sulaiman Bagian Putra Palopo, Adapun pokok masalahnya yaitu: Bagaimana Penerapan Model Pembelajaran Kooperatif Tipe Jigsaw dan menyelidiki Apakah Penerapan Model Pembelajaran Kooperatif Tipe Jigsaw dapat meningkatkan hasil belajar. Penelitian ini merupakan penelitian tindakan kelas (PTK) adapun sumber data dari penelitian ini adalah peserta didik kelas VIII Pesantren Modern Datok Sulaiman Bagian Putra Palopo pada saat diterapkan metode pembelajaran kooperatif tipe Jigsaw, untuk memperoleh data peneliti menggunakan teknik observasi, dan tes. Analisis data dilakukan dengan menggunakan analisis kualitatif deskriptif, dan kuantitatif. Hasil penelitian menunjukkan bahwa dengan menggunakan pembelajaran kooperatif tipe Jigsaw hasil belajar peserta didik setiap siklusnya mengalami perubahan secara signifikan. Secara berturut-turut berdasarkan siklus I dan siklus II hasil belajar akidah akhlak dengan materi pokok beriman kepada kitab-kitab Allah. Pada siklus I nilai tertinggi adalah 87 dan nilai terendah adalah 70. Pada siklus II nilai tertinggi adalah 95 dan nilai terendah adalah 80, berdasarkan analisis ratarata nilai perolehan peserta didik pada siklus I adalah 80,14 sedangkan pada siklus II rata-rata nilai perolehan peserta didik meningkat sebesar 88,32.
\end{abstract}

Kata Kunci: Hasil Belajar, Pembelajaran Kooperatif, Jigsaw. 


\section{Pendahuluan}

Pendidikan akidah akhlak mempunyai arti dan peranan penting dalam membentuk tingkah laku peserta didik seutuhnya, sebab dengan pendidikan akidah akhlak ini peserta didik tidak diarahkan kepada pencapaian kebahagiaan hidup di dunia saja, tetapi juga untuk kebahagiaan di akhirat kelak. Pendidikan akidah akhlak bertujuan menumbuhkan pola tingkah laku peserta didik yang bulat melalui latihan kejiwaan, kecerdasan, perasaan, dan panca indra. Untuk mewujudkan tujuan tersebut harus ditunjang dengan berbagai faktor, seperti di antaranya guru atau peserta didik, lingkungan, motivasi, dan sarana yang relevan.

Kenyataan tersebut menunjukkan perlu adanya pembaharuan dalam proses kegiatan pembelajaran terhadap materi-materi mata pelajaran akidah akhlak. Perlu adanya penerapan model pembelajaran yang dapat merangsang kemampuan penalaran peserta didik. Dan juga perlu penerapan model pembelajaran yang dapat merangsang peserta didik untuk aktif dalam kegiatan pembelajaran.

Salah satu model pembelajaran yang biasa dikembangkan adalah model pembelajaran kooperatif. Kooperatif muncul dari konsep bahwa peserta didik akan lebih mudah menemukan dan memahami konsep yang sulit jika mereka saling berdiskusi dengan temannya. Tujuan diterapkannya model pembelajaran kooperatif adalah sebagai usaha untuk meningkatkan partisipasi peserta didik, meningkatkan pemahaman peserta didik dalam memahami konsep-konsep yang sulit dan mengajarkan keterampilan sosial dan membantu peserta didik dalam menumbuhkan kemampuan berpikir kritis.

Pembelajaran kooperatif merupakan model pembelajaran dengan menggunakan sistem pengelompokan/ tim kecil, yaitu antara empat sampai enam orang yang mempunyai latar belakang kemampuan akademik, jenis kelamin, ras, atau suku yang berbeda (heterogen). Sistem penilaian dilakukan terhadap kelompok. Setiap kelompok akan memperoleh penghargaan (reward). Jika kelompok mampu menunjukkan prestasi yang dipersyaratkan. Setiap individu akan saling membantu, mereka akan mempunyai motivasi untuk keberhasilan kelompok, sehingga setiap individu akan memiliki kesempatan yang sama untuk memberikan konstribusi demi keberhasilan kelompok. ${ }^{1}$

Pembelajaran kooperatif merujuk pada berbagai macam metode pengajaran, di mana para peserta didik bekerja dalam kelompok-kelompok kecil untuk membantu satu sama lainnya dalam mempelajari materi pelajaran.

\footnotetext{
${ }^{1}$ Wina Sanjaya, Strategi Pembelajaran Berorientasi Standar Prosesi Pendidikan (Jakarta Kencana Prenadamedia Group, 2014), h 242-243.
} 
Dalam kelas kooperatif, para peserta didik diharapkan dapat saling membantu, saling berdiskusi. Untuk mengasah pengetahuan yang mereka kuasai. $^{2}$

Strategi pembelajaran kooperatif tipe jigsaw dikembangkan oleh Ellot Arronson dan kologennya. ${ }^{3}$ Artinya jigsaw dalam bahasa Inggris adalah gergaji ukir. Pada dasarnya, dalam strategi ini guru membagi satuan informasi pembelajaran yang besar menjadi komponen-komponen lebih kecil. Peserta didik dikelompokkan menjadi kelompok-kelompok kecil heterogen seperti pengelompokkan pada strategi pembelajaran student teams achievemen division (STAD) yang dinamakan kelompok asal.

1. Strategi pembelajaran Kooperatif Tipe Jigsaw mempunyai beberapa kelebihan dan kekurangan di antaranya:

Kelebihan:

a). Peserta didik lebih dapat berkonsentrasi pada proses pembelajaran.

b). Peserta didik tidak terlalu menggantungkan kepada guru, tetapi dapat menambah kepercayaan kemampuan berfikir sendiri, menentukan informasi dari berbagai sumber, dan belajar dari peserta didik lainnya.

c). Dapat mengembangkan kemampuan mengungkapkan ide atau gagasan dengan kata-kata secara verbal dan membandingkannya dengan ide-ide orang lain.

d). Dapat membantu peserta didik untuk respek kepada orang lain dan menyadari akan segala keterbatasannya serta menerima segala perbedaan.

Kekurangan :

Jika peneliti tidak mengingatkan agar peserta didik selalu menggunakan keterampilan kooperatif dalam kelompok masing-masing, di khawatirkan kelompok akan macet dalam pelaksanaan diskusi, jika anggota kelompoknya kurang akan menimbulkan masalah, membutuhkan waktu yang lebih lama dan masih banyak peserta didik yang masih malu untuk bertanya kepada gurunya. ${ }^{4}$

Adapun faktor penghambat dan solusinya adalah guru dan peserta didik masih terbiasa dengan model pembelajaran konvensional dan terbatasnya waktu yang dibutuhkan dalam pelaksanaan Jigsaw. Dan menjadi sebuah solusi yang efektif apabila diterapkan dalam pembelajaran terhadap bagian dari materi ajar tersebut.

a. Tahap Pelaksanaan Jigsaw

\footnotetext{
${ }^{2}$ Robert E. Slavin, Coomperative Learning, teori, Riset dan Praktik (Narulita Yusron) (Bandung : Nusa Media, 2005), h 4

${ }^{3}$ Husnul Khotimah, Yuyun Strategi Pembelajaran untuk Penelitian Tindakan Kelas (Malang: Sirya Pena Gemilang,2009), h .69

${ }^{4}$ Ibid, h 91
} 
1) Peneliti merencanakan pembelajaran yang akan dihubungkan beberapa konsep dalam satu rentang waktu secara bersamaan misalnya pada mata pelajaran Akidah akhlak di SMP peserta didik akan mempelajari beriman kepada Kitab- kitab Allah. Konsep yang akan dipelajari yaitu : memahami makna beriman kepada Allah, bukti kebenaran kitab Allah Swt, fungsi dan dan isi kitab-kitab Allah Swt dan perilaku orang yang beriman kepada kitab-kitab Allah Swt. Tentu saja perlu menyiapkan RPP dengan menerapkan model Jigsaw.

2) Siapkan materi pelajaran untuk masing-masing konsep yaitu: memahami makna beriman kepada Allah Swt, bukti kebenaran kitab Allah Swt, fungsi dan isi kitab-kitab Allah Swt dan perilaku orang yang beriman kepada kitab-kitab Allah Swt.

3) Peneliti menyiapkan kuis sebanyak 4 jenis sesuai materi yang akan peserta didik pelajari.

4) Bagilah kelas dalam 4 kelompok. Peneliti manyampaikan pengantar diskusi kelompok dengan menjelaskan secara singkat (1) topik yang akan dipelajari masing-masing kelompok, (2) tujuan dan indikator belajar yang diharapkan, (3) bentuk tagihan tiap kelompok, (4) prosedur kegiatan, (5) sumber belajar yang dapat pesreta didik gunakan.

5) Guru menginformasikan tentang pembagian kelompok yang telah dilakukan pada pertemuan sebelumnya dan peserta didik diminta agar mengingat nama kelompoknya dan mengatur tempat duduk peserta didik agar setiap anggota kelompok beratatap muka serta guru memberikan permasalahan pada setiap kelompok.

6) Setiap sub kelompok mendalami materi yang diberikan oleh peneliti yang menjadi pegangannya. Mendalami fakta, konsep dan prosedur penerapan konsep agar ilmu yang mereka pelajari dapat disampaikan kembali kepada teman-tamannya. Kegiatan refleksi ini merupakan proses peningkatan penguasaan materi, untuk dijadikan sebagai bahan untuk kelompok yang lain.

7) Setelah mendalami materi yang telah diberikan oleh peneliti. Kelompok 1 yang bertugas untuk memaparkan hasil kelompoknya, setelah itu kelompok 1 menyebar ke kelompok yang lain untuk menjelaskan hasil kelompoknya.

8) Kembali ke posisi semula dan peneliti mengukur hasil belajar peserta didik dengan tes atau kuis. Peneliti dapat menilai tingkat ketuntasan belajar dengan cara membandingkan hasil yang peserta didik capai dengan target yang ditetapkan dalam RPP. 5

Jadi, beberapa tahap pelaksanaan tipe Jigsaw di atas sehingga memudahkan guru dalam melaksanakan proses pembelajaran dan dapat meningkatkan hasil belajar peserta didik.

\footnotetext{
${ }^{5}$ Ibid, h 93
} 
Penelitian ini bertujuan untuk mengetahui penerapan model pembelajaran Kooperatif tipe Jigsaw dan menyelidiki apakah penerapan model tersebut dapat meningkatkan hasil belajar.

\section{Metode Penelitian}

Penelitian ini merupakan penelitian tindakan kelas (Classroom Action Research) dengan subjek penelitian adalah peserta didik kelas VIII Pesantren Modern Datok Sulaiman Bagian Putra Palopo yang berjumlah 28 orang. Teknik pengumpulan data dalam penelitian ini dilakukan dengan beberapa teknik yaitu Observasi dan Tes. Setelah diperoleh data serta sajiannya, dilakukan penilaian keberhasilan tindakan. Penilaian keberhasilan tindakan ditentukan sesuai dengan data yang terkumpul. Adapun rumus yang digunakan yaitu:

$$
\begin{aligned}
& \mathrm{P}=\mathrm{F} / \mathrm{n} \times 100 \% \\
& \mathrm{P}=\text { persentase } \\
& \mathrm{F}=\text { jumlah siswa yang tuntas belajar } \\
& \mathrm{N}=\text { jumlah siswa }
\end{aligned}
$$

Persentase terendah adalah 0\% dan persentase tertinggi adalah 95\%. Pada pembelajaran ini terdapat 5 kriteria penialaian yaitu: sangat baik, baik, sedang, kurang baik, sangat kurang baik.

a) $86-95=$ sangat baik

b) $76-85=$ baik

c) $71-75=$ sedang

d) $66-70=$ kurang Baik

e) $0-65=$ sangat kurang Baik

Subjek penelitian dinyatakan tuntas belajar dengan baik jika berdasarkan lembar observasi, siswa mendapatkan skor dari pengamat minimal berkriteria baik .

\section{Hasil Penelitian}

Berdasakan hasil penelitian diperoleh nilai hasil belajar peserta didik pada guru mata pelajaran Akidah akhlak sebagai perbandingan hasil belajar pra siklus, siklus I, dan siklus II. Adapun data awal yang diperoleh oleh peserta didik sebelum menerapkan model pembelajaran kooperatif tipe Jigsaw diperoleh nilai hasil pembelajaran pra siklus dalam mata pelajaran Akidah Akhlak kelas VIII Pesantren Modern Datok Sulaiman Bagian Putra Palopo masih rendah karena tingkat persentase hasil belajar peserta didik yang tuntas belajar adalah $46 \%$ dan yang belum tuntas 53\%.

Gambaran umum pelaksanaan Tindakan

a. Tindakan siklus I 


\section{1) Tahap perencanaan}

Adapun kegiatan yang dilaksanakan dalam tahap perencanaan ini adalah:

(a) Menelaah materi pelajaran akidah akhlak

(b) Membuat paket pedoman pembelajaran yang meliputi rencana pembelajaran, membuat instrumen penelitian dengan mengacu pada indikator hasil belajar yang ingin dicapai.

(c) Membuat lembar observasi untuk mengamati kondisi pembelajaran berlangsung.

2) Tahap pelaksanaan tindakan

(a) Peneliti memberi salam kepada semua peserta didik

(b) Peneliti mengadakan absensi terhadap kehadiran peserta didik.

(c) Peneliti memberikan informasi awal tentang jalannya pembelajaran yang dilakukan yaitu pembelajaran kooperatif tipe Jigsaw

(d) Peneliti menyampaikan tujuan pembelajaran, yaitu peserta didik diharapkan mampu menjelaskan materi pelajaran pada kelompok masingmasing.

(e) Peneliti melaksanakan pembelajaran dengan metode Jigsaw sedangkan peneliti mengamati, menilai melalui lembar observasi atau mengamati serta mencatat apa yang terjadi di dalam kelas pada siklus I terkait dengan pelaksanaan pembelajaran akidah akhlak.

(f) Peneliti menginformasikan tentang pembagian kelompok yang telah dilakukan pada pertemuan sebelumnya dan meminta peserta didik agar mengingat nama kelompoknya dan mengatur tempat diuduk peserta didik agar setiap anggota kelompok beratatap muka serta guru memberikan permasalahan pada setiap kelompok.

(g) Peneliti menganjurkan agar peserta didik dalam kelompok melakukan diskusi kecil sebagai aktivitas dalam pembelajaran Jigsaw dan guru berkeliling untuk mengawasi dan memberikan bimbingan terhadap peserta didik dalam menyelesaikan dalam tugas kelompok.

(h) Setiap anggota kelompok menyampaikan hasil diskusi kecil kelompoknya kepada kelompok lain melalui salah satu anggotanya yang dikirim pada diskusi kecil antar kelompok, dan guru memberi kesempatan kepada setiap peserta didik untuk bertanya.

(i) Kembalikan posisi seperti semula untuk mengulas lagi seandainya admasalah yang belum dipecahkan, setelah menyelesaikan permasalahan secara tuntas, peneliti melaksanakan evaluasi dengan membagikan soal kepada peserta didik untuk dikerjakan.

3) Tahap observasi dan evaluasi

(a) Deskripsi hasil observasi

Tahap observasi pada siklus I tercatat sikap yang terjadi pada setiap peserta didik terhadap pelajaran akidah akhlak. Sikap peserta didik tersebut 
diperoleh dari lembar observasi pada setiap pertemuan yang dicatat pada setiap siklus. Lembar observasi digunakan untuk mengetahui perubahan cara mengajar guru dan sikap peserta didik selama proses belajar mengajar berlangsung di kelas pada setiap pertemuan.

(b) Deskripsi hasil belajar

Pada siklus I ini dilaksanakan tes hasil belajar yang berbentuk ulangan untuk melihat sejauh mana peningkatan hasil belajar akidah akhlak peserta didik. Peserta didik harus bertanggung jawab secara individual terhadap hasil belajarnya adapun data skor belajar dari tes siklus I dapat dilihat pada tabel 1

Tabel 1. Distribusi Frekuensi dan Presentase Skor Nilai Peserta Didik Siklus I

\begin{tabular}{|c|c|c|c|c|}
\hline No & $\begin{array}{l}\text { Nilai } \\
\text { Angka }\end{array}$ & Kategori & Frekuensi & $\begin{array}{c}\text { Persentase } \\
(\%)\end{array}$ \\
\hline 1 & $86-95$ & Sangat Baik & 3 & $10,17 \%$ \\
\hline 2 & $76-85$ & Baik & 20 & $67,86 \%$ \\
\hline 3 & $71-75$ & Sedang & 3 & $10,17 \%$ \\
\hline 4 & $66-70$ & Kurang baik & 2 & $6,79 \%$ \\
\hline 5 & $0-65$ & Sangat kurang baik & - & - \\
\hline \multicolumn{3}{|c|}{ Jumlah } & 28 & $95 \%$ \\
\hline
\end{tabular}

4) Tahap refleksi

Pembelajaran dengan penerapan model kooperatif tipe Jigsaw sudah berjalan sesuai dengan prosedur yang telah direncanakan. Namun, sebagian peserta didik masih kurang berpartisipasi dalam mengikuti pembelajaran dengan serius. Selain itu peserta didik masih merasa enggan dan malu untuk mengajukan pertanyaan kepada guru sehubungan dengan materi yang diajarkan. Pertanyaan hanya diajukan oleh sebagian kecil peserta didik pada siklus pertama berlangsung. Permasalahan lain yang dapat diamati peneliti adalah peserta didik masih malu untuk menjawab pertanyaan dari guru. Terlihat pada hasil observasi siklus pertama keaktifan belajar peserta didik hanya mencapai presentase $80,14 \%$.

b. Tindakan Siklus II

Pada dasarnya tindakan pada sikulus II hampir sama dengan siklus I, hanya saja dengan beberapa perbaikan yaitu mendorong siswa untuk semakin aktif dengan cara mengajukan beberapa pertanyaan serta meminta siswa untuk menyiapakan pertanyaan. Kelompok yang paling bagus akan diberikan hadiah dan yang paling kurang diberikan hukuman. Adapun hasil yang diperoleh pada siklus ini, sebagai berikut: 
Tabel 2. Distribusi Frekuensi dan Presentase Skor Nilai Peserta Didik Siklus II

\begin{tabular}{|c|c|c|c|c|}
\hline No & $\begin{array}{c}\text { Nilai } \\
\text { Angka }\end{array}$ & Kategori & Frekuensi & $\begin{array}{c}\text { Persentase } \\
(\%)\end{array}$ \\
\hline 1 & $86-95$ & Sangat Baik & 20 & $27,14 \%$ \\
\hline 2 & $76-85$ & Baik & 8 & $67,87 \%$ \\
\hline 3 & $71-75$ & Sedang & - & - \\
\hline 4 & $66-70$ & Kurang baik & - & - \\
\hline 5 & $0-65$ & Sangat kurang baik & - & - \\
\hline \multicolumn{3}{|c|}{ Jumlah } & 28 & $95 \%$ \\
\hline
\end{tabular}

\section{Pembahasan}

Aktivitas pembelajaran dilakukan bertujuan untuk meningkatkan keberhasilan belajar peserta didik setelah mengalami proses pembelajaran. Salah satu upaya yang dilakukan untuk mencapai keberhasilan pembelajaran agar efektif dan efesien, yakni penggunaan metode pembelajaran yang sesuai dengan materi yang diajarkan. Dalam mengajarkan mata pelajaran Akidah Akhlak khususnya pada materi beriman kepada kitab-kitab Allah Swt dibutuhkan metode yang membantu peserta didik memahami konsep dan beriman kepada kitab-kitab Allah Swt dengan baik dan benar. Oleh karena itu, penggunaan model pembelajaran kooperatif tipe Jigsaw diharapkan mampu memberi pengetahuan dan pemahaman lebih bagi peserta didik melalui pengalaman langsung. Model pembelajaran kooperatif tipe Jigsaw adalah model pemberian kesempatan kepada peserta didik perorangan atau kelompok untuk dilatih melakukan suatu pembuktian kebenaran suatu teori. Dengan penerapan model pembelajaran kooperatif tipe Jigsaw pembelajaran akan lebih efektif. ${ }^{6}$

Sesuai dengan teori di atas penelitian tindakan kelas dengan menerapkan model pembelajaran kooperatif tipe Jigsaw pada mata pelajaran Akidah akhlak yang dilakukan dalam dua siklus didapatkan data bahwa peserta didik kelas VIII. Pesantren Modern Datok Sulaiman Bagian Putra Palopo dapat menuntaskan KKM dasar dengan baik dengan perolehan nilai rata-rata mencapai $88,32 \%$. Hal ini dapat dilihat dari peningkatan hasil belajar peserta didik mulai dari nilai awal peserta didik, siklus I dan siklus II.

Setelah peneliti berlangsung, peneliti melakukan tes wawancara kepada guru mata pelajaran Akidah akhlak kelas VIII yakni setelah belajar dengan model tipe Jigsaw sangat baik.

\footnotetext{
${ }^{6}$ Ismail Sukardi, Model dan Metode Pembelajaran Modern: Suatu Pengantar, (Palembang: Tunas Gemilang Press, 2011), h. 28
} 
Adapun data perincian tentang skor hasil belajar peserta didik selama penelitian dari tahap sebelum tindakan, siklus I sampai siklus II yaitu sebagai berikut:

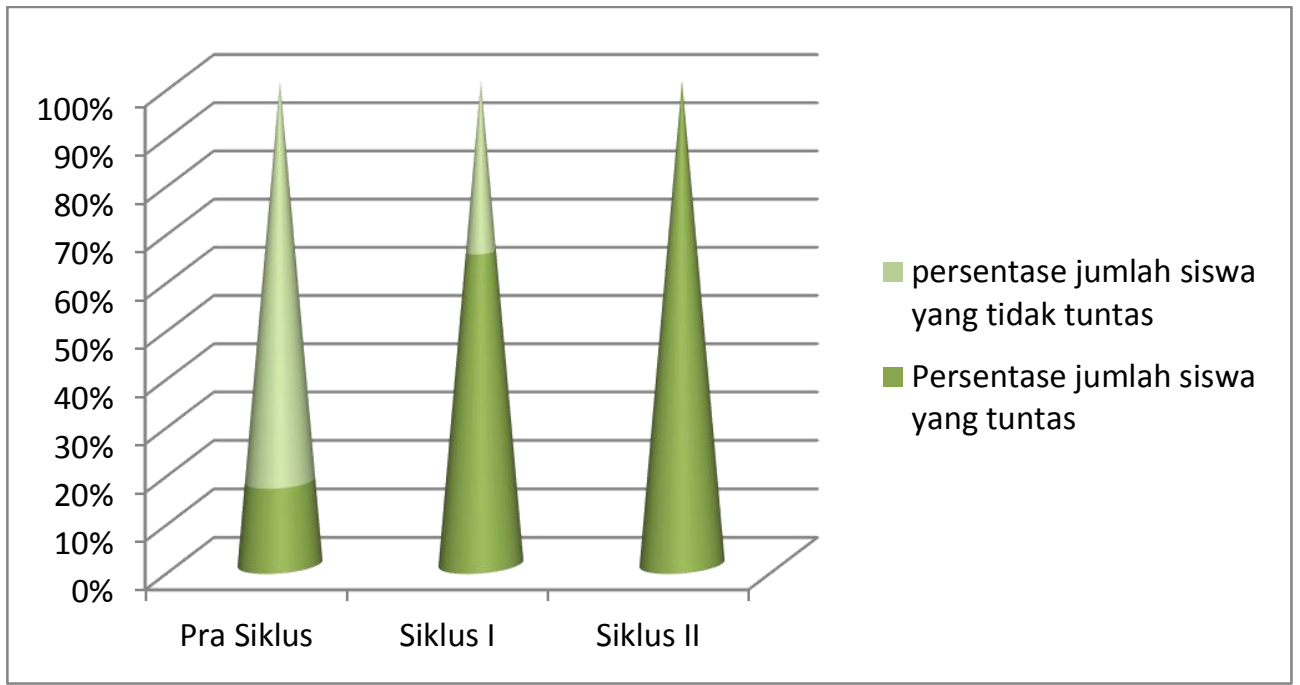

Gambar 1. Diagram Ketuntasan hasil belajar

Pengembangan hasil belajar peserta didik melalui model pembelajaran kooperatif tipe Jigsaw merupakan suatu usaha untuk meningkatkan hasil belajar pada peserta didik yang merupakan awal dari pembelajaran agar baik dan benar. Seperti mengetahui beriman kepada kitab-kitab Allah Swt, contohnya memahami makna beriman kepada kitab-kitab Allah Swt, bukti kebenaran kitab-kitab Allah Swt dan sebagainya. Jadi dalam memahami tujuan beriman kepada kitab-kitab Allah Swt peserta didik harus memiliki keterampilan dalam membaca. Dalam proses pembelajaran tersebut guru harus mempunyai model yang bervariasi dalam pelajaran Akidah akhlak, khususnya pembahasan tentang beriman kepada kitab-kitab Allah Swt. Seperti model pembelajaran kooperatif tipe jigsaw yang mengajarkan peserta didik dengan menggunakan buku cetak memperkenalkan materi beriman kepada kitab-kitab Allah Swt secara sekaligus, dalam mengajarkan beriman kepada kitab-kitab Allah Swt, dan sebaginya. Karena model yang baik adalah model yang mendorong anak untuk belajar dengan baik.

\section{Penutup}

Model Pembelajaran Kooperatif Tipe Jigsaw dapat meningkatkan hasil belajar peserta didik Kelas VIII Pesantren Modern Datok Sulaiman Bagian Putra Palopo. Sebelum diterapkan model tipe Jigsaw, skor nilai rapor peserta didik yaitu 76,14\% dan perlu ditingkatkan lagi dengan itu peneliti menerapkan model Jigsaw dengan model belajar secara berkelompok dan skor hasil kompetensi peserta didik pada siklus I mencapai 80,14\% dan skor siklus II lebih meningkat dari hasil yang sebelumnya menjadi 88,32\%. Jadi penerapan model tipe Jigsaw dapat meningkatkan hasil belajar peserta didik. 
Faktor penghambat dan solusi Model Pembelajaran Kooperatif Tipe Jigsaw Pada Mata Pelajaran Akidah Akhlak Kelas VIII Pesantren Modern Datok Sulaiman Bagian Putra Palopo, yaitu guru dan peserta didik asing dengan model Jigsaw. Baik peserta didik maupun guru masih terbawa dengan model pembelajaran konvensional, yang di dalamnya materi ajar diberikan hanya satu arah yaitu dari guru kepada peserta didik, terbatasnya waktu yang dibutuhkan dalam pelaksanaan model Jigsaw lebih banyak pada pembelajaran konvensional. Model pembelajaran Jigsaw akan menjadi sebuah solusi yang efektif apabila diterapkan dalam pengajaran terhadap bagian dan materi ajar tersebut.

\section{Daftar Pustaka}

Amirul Hadi dan Haryono, Metodologi Penelitian dan Pendidikan (Cet. III; Bandung (Pustaka Setia,2005).

Arikunto Suharsimi,. Dasar-dasar Evaluasi Pendidikan. Jakarta: Bumi Aksara 2009.

Aunurrahman, Belajar dan Pembelajaran, (Cet. VIII; Bandung: Alfabeta, 2013).

Eko Putro Widoyoko, Penilaian Hasil Pembelajaran Di Sekolah, (Yogyakarta:Pustaka pelajar). 2014

Http://belajarpsikologi.com pengertian-prestasi-belajar/juni 2016

Ismail Sukardi, Model dan Metode Pembelajaran Modern: Suatu Pengantar, (Palembang: Tunas Gemilang Press, 2011)

Kementrian Agama Al-qur'an dan Terjemahnya, (Solo, 01 Januari 2015)

Nasution,M.A, Didaktik Asas-asal Mengajar,(Jakarta :PT Bumi Aksara 2000.

Robert Slavin E., Coomperative Learning, Teori, Riset dan Praktik (Narulita Yusron) (Bandung : Nusa Media,) 2005.

Rochiati Wiriatmaja, Metode Penelitian Tindakan Kelas (Bandung: PT Rosda Karya, 2005).

Sayyid, Sabiq Al-Aqidah al-Islamiah, diterjemahkan oleh Moh. Abda'I Rathomy, dengan judul Aqidah Islam (Ilmu Tauhid) (Cet. VI; Bandung : Di ponegoro, 1985).

Shoimin Aris, 2016 dkk 68 Model Pembelajaran Inovatif dalam Kurikulum 2013,(Yogyakarta:Ar-ruzzmedia).

Skinner, Belajar dan Pembelajaran ( Jakarta : Rineka Cipta, 2009)

Sudjana Nana, Penilaian Hasil Belajar Mengajar, (Bandung: Remaja Rosdakarya, 2006),

S Syamsu, Strategi Pembelajaran Menigkatkan Kompetensi Guru (Makassar Sulawesi selatan : aksara timur) 2015.

Syah Muhibbin, Psikologi Pendidikan dengan Pendidikan Baru, (Cet. IV; Bandung:Remaja Rosdakarya,2000), 
Taniredja Tukiran, dkk., Model-model Pembelajaran Inovatif, (Bandung: Alfabeta, 2011

Trianto, Model-Model Pembelajaran Inovatif Berorientasi Konstruktivistik (Jakarta: Prestasi Pustaka,) 2011.

Sanjaya Wina, Strategi Pembelajaran Berorientasi Standar Prosese Pendidikan (Jakarta Kencana Prenadamedia Group) 2014.

Yatimi Abdullah. Studi Ahklak dalam Perspektif al-Qur'an. (Jakarta:Amzah, 2007).

Yuyun Husnul Khotimah, Strategi Pembelajaran untuk Penelitian Tindakan Kelas (Malang: Sirya Pena Gemilang,) 2009. 
186 |Haerati, dkk/ IQRO: Journal of Islamic Education Vol. 2, No.2, Desember 2019. 175-186

Halaman ini sengaja dikosongkan 